\title{
微生物生体膜におけるタンパク質の移行と分泌
}

\author{
依田 幸司・門倉 広・山崎 真狩
}

東京大学農学部農芸化学科 $\mathbf{T} 113$ 東京都文京区弥生 1-1-1

\section{Translocation and Secretion of Proteins across Microbial Membrane}

\author{
Koji YodA, Hiroshi KaDOKURA and Makari YAMASAKI
}

Department of Agricultural Chemistry, University of Tokyo, Yayoi 1-1-1, Bunkyo-ku, Tokyo 113

Microorganisms secrete proteins into medium or translocates them in specific locations in the cell. The mechanisms of translocation and secretion of proteins in microorganisms and in mammalian organella are found to be similar in many respects. Most proteins to be localized outside of cytoplasm have an amino-terminal extension called signal sequence. Genetic studies in Escherichia coli were effectively done in place of biochemical studies in mammalian cells. Analyses of mutations in signal sequence proved this peptide is essential for translocation or secretion. Machinery essential for protein translocation or secretion has been found in mammalian cells such as Signal Recognition Particle or its receptor on endoplasmic reticulum. Though such machinery is yet to be found in microorganisms, existence of their counterparts is supported by analysis of temperature-sensitive mutations such as sec $A$ or sec $Y$ defective in protein translocation and secretion. In vitro translocation and secretion systems using inverted bacterial membrane vesicles showed many proteins can translocate or secrete not only co-translationally but also post-translationally, $i$. e. after the protein synthesis has been completed. In vitro systems were also effectively studied to show that ATP is a major energy source of protein translocation or secretion.

Key words : Secretion, Translocation, Signal sequence

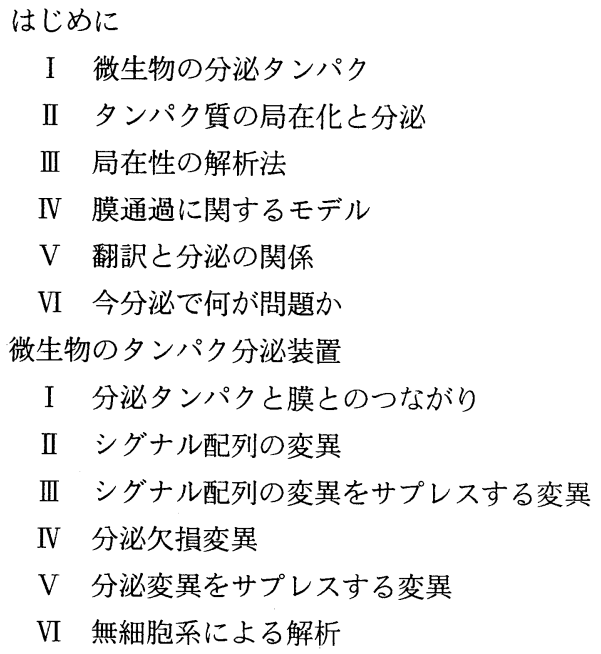

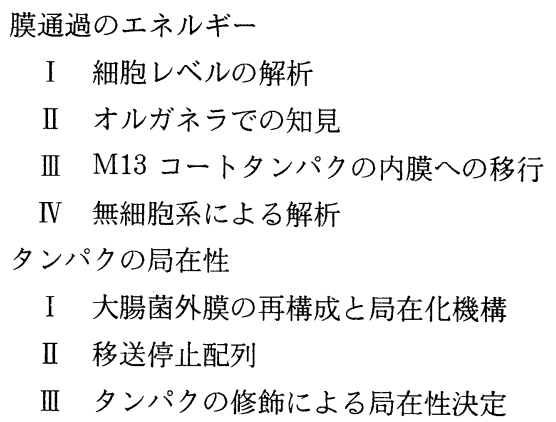

I 微生物の分泌タンパク

多くの微生物は様々の物質を細胞外に放出している. 
その中には，プロテアーゼ，アミラーゼ， ヌクレアーゼ など加水分解酵素が主であるが，タンパク質も分泌され ている．納豆は納豆菌 Bacillus natto の分泌するプロ テアーゼ，アミラーゼ等の酵素作用などにより大豆を加 工して栄養価を高めた微生物加工食品であるし, 胃腸薬 などに使われるタカジアスターゼは麴菌 Aspergillus oryzae の分泌する菌体外醭素の粗精製物である，界面 活性剤に対して安定な細菌菌体外プロテアーゼは污れ落 しの補助剂として洗剤に添加されている．また遺伝子操 作技術を用いた有用タンパク生産の際に，生産性の増大 之精製工程の効率化のために，その産物を分泌させる技 術の開発も期待されている。

微生物の培養液中に生産される分泌タンパクが, どの ような機構で作られるのかということは非常に興味深い 問題であるが，すべての微生物について同じように詳細 な生化学的解析が進められているわけではない，基礎的 な解析が進められているのは, 既にある程度生化学的・ 遺伝学的な知識が蓄積している微生物に限られている. 原核微生物の細菌ではグラム陰性の大腸菌 Escherichia coli，グラム陽性の枯草菌 Bacillus subtilis，真核微生 物の子囊菌ではパン酵母 Saccharomyces cerevisiae が大部分の研究で対象とされている。これらが代表的な 研究対象であり, 他の微生物の機構はそれとの類似性を ふまえて比較検討されている.

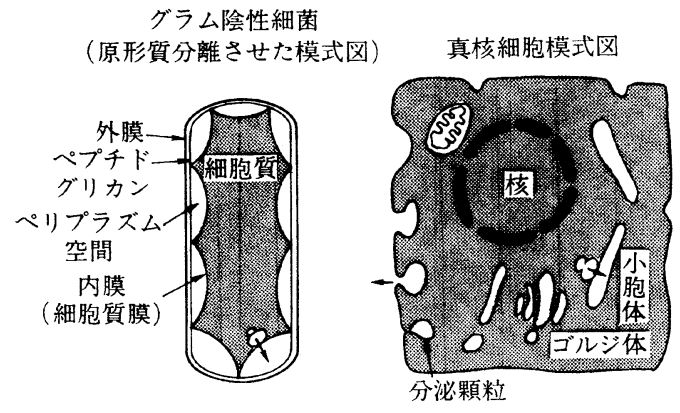

Fig. 1 細胞の構造と分泌 $\$$ リボソームと分泌 方向を示す.

細胞の大きさ，各成分の大きさはもちろん 正確でない。

これら 3 種の微生物のうち, 真核微生物である酵母に おけるタンパク質の分泌機構は遺伝的・生化学的解析の 結果, 動物の分泌組織である膵臓の細胞におけるのとほ とんど同じであることが明らかになってきている.即ち，
膵臟細胞に比べればほとんど発達していないようにみえ るが，とにかく酵母にも小胞体は存在し，まずここに分 泌タンパクや膜タンパクは翻訳と共役して入り込み, ゴ ルジ小胞における修飾を経て分泌顆粒に移行して, 最後 は exocytosis により細胞質膜或はその外側に至るので ある. 酵母の最外表層には主にグルカンとマンナンタン パクからなる頑強な細胞壁があるので, 分泌タンパクの ほとんどはここに蓄積し，これを通り過して培地中にま で出ていくタンパクは稀で特殊な機構をもつものといえ る.

一方, 細胞内にオルガネラを発達させていない原核微 生物においては, タンパクが通過する膜は唯一細胞全体 を包んでいる細胞質膜であり，分泌のために特に分化し た膜ではない，様々な栄養素を吸収したり ATP を生 産したりしている膜とつながっているひとつの膜であ る. そのため, 本稿でもこれから述べるように, 基本的 にはすべての生物でタンパクの膜通過機構は同じである と考えられるが, 細菌には細菌の特殊な機構が存在して いることも明らかになってきた。

本稿では微生物のうち主に大腸菌について明らかにさ れてきた点について述べ，関連する部分で他の微生物に 関する知見に触れることとしたい，必要に応じて高等生 物のオルガネラについても言及することとなろう。

\section{II タンパク質の局在化と分泌}

そもそも，オルガネラ内でわずかに行われるタンパク 合成を除いて，すべてのタンパクは細胞質内で合成され ている. 生物がもつタンパク合成活性のある装置は唯一 リボソームであり，アミノ酸のついた tRNA やペプチ ド伸長因子やエネルギー源となる GTP なよ゙タンパク質 合成に必要なすべての成分とともに細胞質の可溶性成分 として存在している.したがって細胞質以外の領域に存 在するタンパクはすべて翻訳中あるいは翻訳後に何らか の機構でそれらの領域に移行してゆくわけである．分泌 というのはこのようなタンパクの局在化機構の一つであ るととらえるのが，この問題を普遍的に解析する上で重 要なとらえかたである。

細菌のうちグラム陽性のものでは, 細胞質膜に埋め込 まれているタンパクとその膜を通過して培地中に放出さ れるタンパク,この 2 種が細胞質以外の領域に行くタン パクである，一方，グラム陰性細菌では，細胞質膜は内 膜ともよばれ，その外側にもう一つリン脂質とタンパク とリポ多糖とからなる膜構造である外膜をもっている. 従って, 細胞質膜を通過したタンパクは, 外膜にさえぎ 
られて内膜と外膜に挟まれたペリプラズムと呼ばれる空 間にとどまるか，外膜に局在化するか，特殊な例で培地 中に放出されて行くことになる．この場合，細胞質以外 というのは, 内膜・ペリプラズム・外膜・培地中の 4 つ の領域ということができる.

\section{III 局在性の解析法}

なにごともそうであるが実際の研究においては，対象 に選んだタンパクが分泌したか否か，特定の領域に局在 化できたか否かを決定する方法の善し悪しが結果を左右 させることがある. 本題に入る前にこの点について少々 言及しておきたい．

（A）菌体外タンパク：培地中まで分泌する場合は単 に遠心分離やメンブレン・フィルターろ過によって除菌 した培養液を検討すればよいのであるが，特に長時間培 養した場合などには細胞の溶菌により内容物が非特異的 に出てきていることがあるので， $\beta$-ガラクトシダーゼ のような細胞質のマーカータンパクの有無についての チェックが必要である.

（B）ペリプラズムタンパク：グラム陰性菌のペリプ ラズム空間に存在する成分は, Heppel ら ${ }^{1)}$ が開発した 浸透圧ショック法により特異的に抽出することができ る.この方法は, 蔗糖の高張液にさらして原形質分離を おこした細胞を集め, 低温に保ったごく低浸透圧のバッ ファないし水に急速に懸濁するのである.この過程で細 胞のコロニー形成能をほとんど失わせずにペリプラズム 成分が外液に放出される. 但し高張液中に入れる EDTA の濃度を增したりショック外液の塩濃度を水に近付ける ことにより，コロニー形成能は低下し，ペリプラズム画 分の放出効率は上がる. また対数增殖期の細胞の方が静 止期の細胞より放出効率が一般に高い。この場合も溶菌 のチェックが必要である.

(C) 膜タンパク：グラム陰性菌の内膜と外膜を分け る方法としては, 三浦と水島が最初に発見した両者の比 重の違い ${ }^{2)}$ を利用して, 密度勾配平衡遠心により軽い内 膜と重い外膜を分けるのが最も正確である。これについ ては様々な具体的手法が報告されている ${ }^{3-6)}$. また簡便 法としては界面活性剂に対する外膜の抵抗性を利用した 方法がある. 即ち, Triton X-1007) とかザルコシル8 とかの界面活性剂は内膜タンパクを可溶化させるが，外 膜タンパクは溶けずに残る. SDS のような強力な変性 作用を持つ界面活性剂でも $50{ }^{\circ} \mathrm{C}$ 以下で処理すれば一部 の外膜タンパクはペプチドグリカンに付いたまま溶けず に残る ${ }^{9)}$ 。しかし界面活性剤を用いた方法はあくまで補
助的なものと考えたほうがよい。

（D）プロテアーゼ感受性：膜を通過したか否かを一 般的に調べる方法として重要なのは, プロテアーゼが生 体膜を通過しないことを利用して，プロテアーゼに対す るタンパクの感受性をチェックするものである． 細胞全 体を膜の袋にしたと考えられるプロトプラストやそれに まだ壁成分が付着しているスフェロプラストについて は, 袋の内側にあるものは膜に守られて外から加えたプ ロテアーゼで消化されないが, 膜から出てしまった部分 は分解される，無細胞タンパク合成系に加えた膜小胞を 用いた実験などでは, 膜小胞の中に入り込まなかったも のはプロテアーゼで消化され, 膜小胞の中に移行できた ものは消化されない(0). タンパクそのものがプロテ アーゼ耐性でないということは, 界面活性剂で膜を溶か してしまうとすべて同じように分解されるということで 示すことができる.

（E）シグナル配列の切断：多くの分泌タンパクはN 末端に疎水性アミノ酸に富むシグナル配列をもつ前駆体 として合成され, 分泌に際してシグナル配列は切除され る.このような場合は, 特に無細胞系の実験において, シグナル配列の切断除去が膜の通過と同時に起きるとい う前提のもとに，シグナル配列を切断されたものと切断 されていないものの比率を電気泳動ゲルから読み取っ て，膜を通過したものの比率とすることができる11). しかし，大腸菌のタンパクについてはこのシグナル配列 の切断之分泌の関係は動物の分泌系でみられるように同 時的なものではないようなのでそのまま応用できな (12).

いずれにしても，できるならば一つの方法に頼らず， 2 つ以上の方法により検討することが望ましい. 例えば, 大腸菌の $\beta$-ラクタマーゼの分泌について，そのC末端 を欠失したような変異を作って検討したところ，浸透圧 ショック法で外液に回収されず，C 末端が分泌に必須で あるという結論が提出されたことがある ${ }^{13)}$. しかし， 後に外から加えたプロテアーゼに感受性であることか ら，C 末端を欠いた $\beta$-ラクタマーゼも内膜の外侧に出 ていることが確認され，膜通過は $C$ 末端が無くても正常 に起こるが，できあがったポリペプチドが構造的に安定 でなく変性不溶化し浸透圧ショック法で回収されなかっ たということが分かった ${ }^{14)}$.

\section{IV 膜通過に関するモデル}

動物, 植物, 微生物を問わず, タンパクが生体膜を通 過する機構が一般に共通であるという認識は，既にいま 


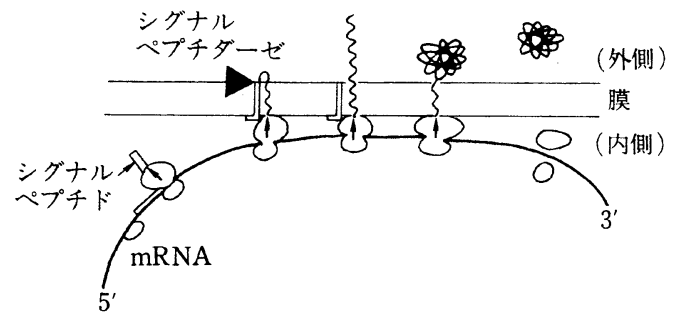

Fig. 2 Co-translationnal な分泌のシグナル仮説 模式図

さら本稿で改めて述べるまでもない。これまでに優れた 総説が数多く掲載されている ${ }^{12,15-28)}$. 以下はこの分 野に関わられておられない方の便宜ために簡単に述べる ので, 詳細は他の総説を参照していただきたい.

タンパクの膜通過に関して最も卓越したモデルは, 1975 年に Blobel と Dobberstein が提出したシグナル 仮説 ${ }^{10)}$ である.この仮説はマウス白血病細胞のイムノ グロブリン mRNA と小麦肧芽のタンパク合成系とイ 又の膵蒇のミクロゾーム膜小胞というへテロな構成の, 無細胞タンパク分泌系を用いた実験を根拠に大胆な構想 を交えた仮説であったが，いまやそのほとんどの部分に ついて実験的に支持され, より詳細な生化学的機構が明 らかにされている.

（A）初期のシグナル仮説：分泌タンパクをコードし ている mRNA は，普通の細胞質のタンパクと同じよ うに細胞質のリボソームにより翻訳を開始する，最初に $\mathrm{N}$ 末端に合成されるペプチド部分はシグナル配列と呼ば れる蹯水性アミノ酸に富んだもので，これがリボソーム 大亜粒子からでてくると小胞体膜上にあるシグナル配列 のレセプターに認識されて結合する，するとそれがシグ ナルとなって, 小胞体膜にタンパクを通過させる膜タン パクのトンネルが形成され，またりボソームは膜上のリ ボソーム結合タンパクにより小胞体膜に固定される．以 後この膜結合型リボソームにより合成されるタンパクは 小胞体膜を通過して内腔に入り込み，シグナル配列は翻 訳中にシグナルペプチダーゼにより切断される．終始コ ドンに至って翻訳が終了し, リボソームが大小の亜粒子 に解離してしまうとともにそれらは膜から離れる，以上 が最初のシグナル仮説の概要である.

（B）現在のシグナル仮説：その後の研究によりさら に詳細な機構が明らかにされた.リボソームから出てき たシグナル配列は，まず細胞質にある $11 \mathrm{~S}$ シグナル認 識粒子 SRP (Signal Recognition Particle)により認
膜 (MEMBRANE)，Vol.12 No.3 (1987) 135

識され，このSRP はリボソームに結合してタンパク合 成をいったん停止させる. それが小胞体膜上にある SRP レセプターにより認識されると, リボソームは膜に結合 し, SRP はリボソームから離れ, タンパク合成は再開 されて以後は小胞体内に移行される ${ }^{29)}$. SRP は $7 \mathrm{~S}$ の RNA 亡 6 種のタンパクからなる核酸タンパク複合体で Blobel らはリボソームの第 3 の亜粒子と呼んでいる ${ }^{30)}$. 既に遺伝子もクローニングされた小胞体膜の SRP レセ プター ${ }^{31)}$ は, ドッキングタンパクとも呼ばれ, 分子量 72,000 の膜タンパクだが， $\mathrm{N}$ 末端側で膜につなぎと められていてエラスターゼで部分分解すると C 末端側 60,000 の部分が根元を切られたように膜から外れてく る.このものは膜と混ぜれば活性が再構成される. シグ ナルペプチダーゼも 6 種のタンパクからなる複合体とし て精製されている ${ }^{22)}$.

（C）ループモデル : Blobel のシグナル配列の特徴 づけは, 疎水性アミノ酸に富んだ配列というだけであっ たが, 井上らは細菌のシグナル配列の解析から, 最も $\mathrm{N}$ 末端側にある塩基性アミノ酸がリン脂質二重層の陰荷電 と静電的親和性により結合し, それに続く疎水性アミノ 酸の連続した部分は脂質二重層の脂肪酸側鎖部分との疎 水的親和性によりループ状に潜り込んで行くとした ${ }^{16)}$. また，シグナル配列の内部にあるグリシンやプロリンは 潜り込む過程でペプチド鎖の折れ曲がりに関与し，切断 点のアミノ酸が側鎖の短いものであることは, シグナル ペプチダーゼの基質特異性と関係があると推察した。こ れがループ・モデルと呼ばれるものであるが， あえて夕 ンパクの膜通過のために特別の装置を推定せず, シグナ ル配列そのものだけで分泌の開始が可能であるとする点 に特徴がある.

（D）直接移送モデル：von Heijne ${ }^{33)} も$, 膜を通過 するポリペプチドの個々のアミノ酸については, 水層か ら油層に入り込む際のエネルギー変化は一方で油層から 水層へ出ていく際のエネルギー变化とほぼ収支が合って いるから，一度始まってしまえば全体として特別の装置・ 機構がなくてもタンパクは膜を通過してゆきうるという 考え方を示した。

\section{V 翻訳と分泌の関係}

翻訳後の膜への組み込みに関する Wickner の Membrane Trigger 仮説については後にも具体的に触れる が, Blobel をはじめとするおおくのモデルがタンパク 質の合成と局在化は強く共役していて互いに切り離すこ とができないとしていたのに対して，両者が本質的には 
別々の切り離すことができる独立した過程であり，ただ 時間的にほぼ同時に起きるのだという点に力点を置いた モデルである.

それによると, 膜タンパクの前駆体は細胞質内にも作 られるがシグナル配列の存在により成熟体とは異なる高 次構造をとっている. シグナル配列と膜との出会いによ りタンパクの高次構造に変化が起こって, それにより膜 への組み込みが起こり, 次いでシグナル配列が切断され ると新たな局在場所で安定な高次構造になるというもの である17,19)。

Blobel らが最初に材料に選んだ免疫グロブリンL 鎖 の分泌を始め, 多くの材料については, 分泌タンパクの 合成系のみを組んでタンパクを合成してしまってから, 後で小胞体膜系を加えてもそのタンパクは膜の中に入っ ていかないことから，タンパク合成と分泌は共役してお り，つまり分泌は co-translational に起こる. 大腸菌 などの分必タンパクや膜タンパクでも普通のパルスラベ ル実験では全長の前駆体タンパクが検出されることはほ とんどないので, co-translational にしか局在化はお こならないと考えられていた. しかし，Wickner らの 材料とした M13 ファージコートタンパクでは細胞質に 前駆体タンパクが検出され, タンパク合成が完了してか らでも局在化が起こる，つまり post-translational に も局在化が起こると考えられた.

このようにタンパクの局在化は co-translational か post-translational かという点は長い間激しい争点と なってきたが, 研究対象とするタンパクの種類が増える に従って, 明らかに post-translational な局在化があ ることが証明された。

もっとも決定的だったのは，ミトコンドリアなよ゙のオ
ルガネラのタンパクで主染色体にコードされているもの で，精製した前駆体をオルガネラと混ぜることで局在化 が起こる. 大腸菌の外膜タンパクやペリプラズムタンパ ク $^{34)}$, 酵母の $\alpha$ ファクター ${ }^{35)}$ などでも膜結合型でない リボソームで合成された前駆体タンパクが post-translational に局在化することが無細胞タンパク合成系で 証明された。

\section{VI 今分泌で何が問題か}

タンパクの分泌一般については，先にも述べたように 優れた総説が多数発表されている.したがって，分泌一 般に関してはそれらの総説を参照していただくとして, 本稿では筆者等が興味を持っている側面から微生物の夕 ンパクの膜通過機構について考察してみたい. それは,

「微生物の膜にはタンパクを移行させるための特別な装 置は有るのか?」また「タンパクが膜を通過して行く際 のエネルギー的な問題はどのように考えられているの か?」さらに「あるタンパクが最終的に細胞内の一つの 場所にのみ存在するようになるというタンパクの局在性 はよ゙のようにして決まるのか？」という問題である.

\section{微生物のタンパク分泌装置}

\section{I 分泌タンパクと膜とのつながり}

動物のタンパク分泌に関与している膜結合リボソーム は，ピュロマイシンでペプチド伸長反応を中途で終わら せても, 膜にくっついていて高塩濃度のバッファで処理 しないとはずれない. 即ちリボソームはそれ自体が膜上 のリボソーム結合タンパクと強く結合している. 一方, 細菌の膜結合リボソームはピュロマイシン処理により膜 からはずれてしまう。このことから, 細菌の場合, リボ ソームと膜を結び付けているのは伸長中のペプチド鎖の

Table 1 代表的な大腸菌のシグナル配列

$-25$

$-20$

$-15$
$-10$

$-5$

$-1$
Het-Lys-Lys-Ser-Leu-Val-Leu-Lys-Ala-Ser-Val-Ala-Val-Ala-Thr-Leu-Val-Pro-Met-Leu-Ser-Phe-Ala + Ala

Met-Lys-GIn-Ser-Thr-Ile-Ala-Leu-Ala-Leu-Leu-Pro-Leu-Leu-Phe-Thr-Pro-Val-Thr-Lys-Ala + Arg

Met-Lys-Ile-Lys-Thr-Gly-Ala-Arg-I le-Leu-Ala-Leu-Ser-Ala-Leu-Thr-Thr-Met-Met-Phe-Ser-Ala-Ser-Ala-Leu-Ala + Lys

Het-Lys-Ala-Thr-Lys-Leu-Val-Leu-Gly-Ala-Val-Ile-Leu-Gly-Ser-Thr-Leu-Leu-Ala-Gly + Cys

Met-Met-Ile-Thr-Leu-Arg-Lys-Leu-Pro-Leu-Ala-Val-Ala-Val-Ala-Ala-Gly-Val-Met-Ser-Ala-Gin-Ala-Met-Ala + Val

Met-Lys-Lys-Thr-Ala-Ile-Ala-|le-Ala-Val-Ala-Leu-Ala-Gly-Phe-Ala-Thr-Val-Ala-GIn-Ala + Ala
M13コートタンパク (内膜)

PhoAタンバク (ペリプラズム)

MalEタンパク (ペリプラズム)

リポタンパク（外膜）

LamBタンパク (外膜)

OmpAタンパク (外膜) 
みであると考えられている15).

\section{II シグナル配列の変異}

分泌タンパクが分泌するためにはその $\mathrm{N}$ 末端にあるシ グナル配列が必須と考えられているが，既に上で述べた ように, シグナル配列の特徽は疎水性アミノ酸に富むと いうこと以外余りはっきりしたものがない，最近は共通 の活性を持つ酵素の活性中心とかコファクタ一結合部位 とか，核内への移行配列とかにコンセンサスなアミノ酸 一次配列が指摘されるようになってきたが，シグナル配 列についてはそのような共通一次配列は見いだされな い.アミノ酸の一次配列よりもむしろその二次構造の方 が重要であるとする指摘もある。（いずれにしろ，その配 列之機能の関係を明らかにするには，シグナル配列の変 異株を用いた研究が大いに貢献すると思われる.

（A）分泌能を失うシグナル配列変異：最初にとられ た変異株は，シグナル配列をつけても分泌しない夕ンパ クとして知られる $\beta$-ガラクトシダーゼに LamB タン パクや MalE タンパクのシグナル配列をつけた遺伝子 を作製し，これらを強く誘導発現させたときに細胞が致 死的になる現象を利用して，生き残りの株の中から取得 された ${ }^{36.37)}$. シグナル配列が機能するともともと分泌 できない $\beta$-ガラクトシダーゼがむりやり分泌過程に入 り込み, 分泌装置に異常を起こして致死的になると考え られるので, 分泌能を失ったシグナル配列変異株なら生 き残るわけである. 同じような選択法で PhoA タンパ ク（アルカリ性ホスファターゼ）のシグナルの変異もと られている．これらは何れも疎水性のアミノ酸の並びの 中に塩基性ないし酸性のアミノ酸が入り込んだような変 異である.これにより, シグナル配列の中の疎水性アミ ノ酸の並びが分泌によって必須であることが証明され た.

これらの変異のうちには, 塩基性ないし酸性のアミノ 酸への変化ではなく, プロリンの導入あるいは小さな欠 失変異によってその部分に考えられた $\alpha$ ヘリックスの形 成が阻害されるものも得られており，このことからシグ ナル配列中央部の $\alpha$ ヘリックス構造が分泌に必須である という考えも提出された.

(B) 部位指定变異処理による変異 : 別の一群のシグ ナル配列の変異は, 先に述べた井上のループ・モデルの 証明のために, 彼らのグループが精力的なオリゴヌクレ オチドを用いた部位指定変異処理により作成した，リポ タンパク遺伝子の変異である. $\mathrm{N}$ 末端にある塩基性ア ミノ酸残基が膜のリン脂質と静電的な結合をすることが
シグナル配列の膜との最初の接触に重要な役割を果たす とするこのモデルを支持するように， $\mathrm{N}$ 末端部分のア ミノ酸の荷電を中性に変異させたところ, リポタンパク の膜へのアセンブルは遅くなり, 更に酸性に変異させる と先ず細胞質に可溶性の前駆体が生成し，その後膜に post-translational にアセンブルするようになった ${ }^{38)}$. しかし膜へのアセンブルが完全には阻害されなかったと いうことは $\mathrm{N}$ 末端の塩基性アミノ酸残基の果たす機能が 補助的なものと考えるべきかも知れない，それはこの塩 基性アミノ酸という特徽は細菌のシグナル配列について 共通にみられることで動物のシグナル配列までは必ずし も共通でないということからも考えられる.

III シグナル配列の変異を抑制（サプレス）する変異 上述のようなシグナル配列の変異により分泌ができな くなった変異株から，再び分泌ができるようになった株 を選択するには，例えば LamB タンパクの場合はこれ が外膜に移行しないと細胞はグルコースが 4 つ以上つな がったマルトデキストリンを摂取できなくなるので，マ ルトデキストリンを唯一の炭素源として生育できる株を 選び出せばよい，その中には，完全な復帰変異ではない 様々な興味ある变異株が取得された。一群はシグナル配 列の中で別の変異がおきて最初の变異を抑制(サプレス) したものである．例えば荷電を持ったアミノ酸が荷電の ない疎水性アミノ酸に变わったものが得られている。こ のことはやはりシグナル配列内の疎水的なアミノ酸の並 びがその機能にとって必須であったことを確認させてく れる.

Silhavy 等は，シグナル配列の変異そのものは復帰し ていないのに染色体上の別の位置に新しい変異が起こる ことにより，欠宿のあるシグナル配列でも機能できるよ うになった別の一群の変異株を分離している，特にシグ ナル配列内に欠失をおこしたものでも分泌させることの 出来了変異が得られている.これらは，シグナル配列之 相互作用して分泌に関与している細胞成分が变異するこ とによるサプレッションと考えられた．これらの変異に は prl (protein localization) という名前があたえら れ，A から $\mathrm{F}$ までが染色体上の異なる位置にマップさ れた. $p r l A$ は次に述べる $\sec Y$ 遺伝子と同じもので, リボソームタンパクのオペロン中にコードされる膜タン パクである18.24.26).

\section{IV 分泌次損変異}

及ーガラクトシダーゼは四量体で活性をもつタンパク であるが，そ机に MalE のシグナル配列をもたせた夕 
138 依田・門倉・山崎 : 微生物生体膜におけるタンパク質の移行と分泌

ンパクは，シグナル配列の機能により膜と親和性を持つ ため, 活性が低くなる。ももシグナル配列が機能できな くなるような変異株になれば, このタンパクも細胞質内 に作られるようになって活性が高くなると考えられる. このような検索法で取得されたのが, $\sec A$ 変異株であ る. 大腸菌染色体地図の 2.5 分にマップされるこの遺 伝子の温度感受性変異株では，温度を上げると $\mathrm{MalE，}$ PhoA, LamB, OmpF などいくつかの分泌タンパクの 前駆体が同時に蓄積する ${ }^{39)}$. しかし全ての分必タンパ クで分泌が阻害されてはいないらしい.この $\sec A$ 遺 伝子は形質導入ファージからクローンされ, 分子量 92,000 のタンパクがコードされていることが明らかと なっている40). 更に, $\sec A-l a c Z$ 融合タンパクに対す る抗体を用いた実験から，このタンパクは細胞質膜の細 胞質側に存在していると考えられている ${ }^{41)}$. 同様にし て, 致死変異ではないが $\mathrm{MalE}, \mathrm{OmpF}$ 前駆体が蓄積 する $\sec B$ 変異も取られ, 80.5 分にマップされている ${ }^{42)}$.

伊藤らは, リボソームタンパク $s p c$ オペロンの近傍 の温度感受性変異を領域指定変異処理法により多数分離 L，その中から高温で分泌タンパク MalE や膜タンパ ク $\mathrm{OmpA}, \mathrm{OmpF}$, リポタンパク $(\mathrm{Lpp})$ の前駆体が蓄 積する ts 24 を選び出して解析し, 変異を起こした遺伝 子を $\sec Y$ と命名した ${ }^{43)}$. DNA レベルの遺伝解析よ り, $\sec Y$ は $s p c$ オペロンの下流に位置するこれまで機 能不明だった 443 アミノ酸からなるタンパクをコード するものであった ${ }^{44)}$ ．産物をアイソトープ標識してそ の性質を検討したところ，あらゆる点で膜に埋め込まれ た膜タンパクであると推定された ${ }^{45)}$.

これらの前駆体を蓄積する変異は, その遺伝子の産物 が分泌タンパクの正常な膜通過と膜タンパクの正常な膜 へのアセンブルに必須であるということから，大腸菌の 持つ分泌装置の構成成分の变異であると推定されてい る.ではこのような分泌装置の構成成分の変異は一体い くつとることができるだろうか. 互いに相互作用する夕 ンパクの構造遺伝子の変異は, 次に述べるサプレッサー の検索により，芋づる式に捕まえることが出来ると期待 される.

\section{V 分泌次損変異をサプレスする変異}

サプレッサー变異による関連遺伝子の取得法は, 前の 節でもシグナル配列の変異のサプレッサーとして出てき たが, 最初は P 22 ファージ頭部タンパクのアセンブ リーの解析で考案された方法である ${ }^{46)}$. A という成分 が A’に変異したことによる欠損は，A'が A に戻らな
くても，A 上相互作用する成分 B の B'への変異によ り回復することがある. 即ち, $\mathrm{AB}$ 複合体と $\mathrm{A}^{\prime} \mathrm{B}^{\prime}$ 複 合体の機能がほぼ同等であればよい，A と $\mathrm{A}^{\prime}, \mathrm{B}$ との 違いを見分ける形質として，A'が高温感受性，B'が低 温感受性となったものを選び出せば，即ち A'の高温で の復帰変異株中より低温感受性の $\mathrm{B}^{\prime}$ 变異を分離すれ ば， B 遺伝子のマッピングや産物の解析ができる.

分泌の装置がファージの頭部のように互いに相互作用 を持つ複数のタンパクよりなるのならば，同様の考え方 で高温感受性株を一つ手にいれると，そのサプレッサー として他のタンパクの変異を取得しうるはずである.こ のような期待のもとに, $\sec A$ および $\sec Y$ のサプレッ サー変異株が多数分離された.

$\sec A$ 変異のサプレッサー ssa は D から $\mathrm{H}$ まで, $\sec Y$ のサプレッサー ssy は A から $\mathrm{H}$ まで, 遺伝子地図 上の場所が異なるものが得られている22a).これらが $\sec A, \sec Y$ とともに分泌装置を実際に構成しているか 否か, 分泌によ゙の様に関与しているかはまだあまり明ら かでない.これまでの解析の結果は予想と少し異なって きた. 即ち $s s y A$ のようにタンパク合成の速度を遅く するような变異により分泌能欠損が復帰するという事実 が明らかになってきたのである.

大腸菌でタンパク合成速度の低下がどの様にして分泌 の欠損を回復させるかよく分かっていない. 分必を回復 させるように変異したものを選び出した結果たまたま夕 ンパク合成速度の方が低下してしまったのかも知れな い. タンパク合成の速度が低下する変異を $\sec A$ と組み 合わせて, 分泌欠損形質が回復したという例がある $22 a)$. タンパク合成速度の低下は, タンパク合成開始の頻度が 変わらないなら mRNA あたりのリボソーム数を増加 させ, 言い替えれば合成中のペプチド鎖数を増加させる. 前に述べたように細菌の場合, 膜とリボソームの結合が 合成中のポリペプチド鎖に大きく依存しているなら，こ の数の増大は膜とリボソームの結合を強くし分必装置の 欠損を補いうるのかも知れない.

\section{VI 無細胞系による解析}

真核細胞の分泌機構がごく初期から無細胞タンパク合 成系を駆使して研究されてきたのに対して, 細菌の分泌 機構はこれまでに述べてきたように遺伝学的手法を用い た研究に大きく依存してきた。しかし，大腸菌において も，DNA に依存した無細胞タンパク合成系には Zubay の系というよく知られているものがある. 大腸菌でも分 泌タンパクがシグナル配列を持つ疎水性の前駆体として 
合成され, 膜画分に存在するシグナルペプチダーゼによ り切除されることは, 1977 年アルカリ性ホスファター ゼ $(p h o A)$ 遺伝子を含む形質導入ファージ DNA を用 いたこのタンパク合成系により示されている ${ }^{47)}$. また, 大腸菌の膜小胞を作る方法は, 低分子物質の膜透過系の 研究で早くから開発され, フレンチプレスで破砕すると, 内側と外側が逆になった小胞 (inverted vesicles) が得 られ，等張液中でペプチドグリカンをリゾチームにより 消化後, 低張圧にして破裂させると, 元の細胞と同じ方 向性の小胞 (right-side-out vesicles) が得られ, 超音 波による破砕では両方向混在した小胞 (mixed vesicles) が得られることはよく知られている. このうち inverted vesicles は, いはば動物の小胞体由来のミクロソーム 小胞と同じ方向性を持っているから, 外側にタンパク合 成系を組むことが出来れば，細胞においてはペリプラズ ムに分泌する分必タンパクが膜小胞内に入り込むはずで ある.

$\mathrm{Smith}^{48)}$ は 1980 年この様な系を組んで, アルカリ 性ホスファターゼとジフテリア毒素がプロテアーゼ耐性 な形で小胞内に入り込むことを示した，次いで，この小 胞がタンパク合成終了後に加えては無効であることか ら, 分泌とタンパク合成は共役しているとし, 更に小胞 をあらかじめプロテアーゼで処理しておくと分必活性を 失うことから, 膜の表面に分泌に関与するタンパク性の 成分があることを主張した．この系の追試がごこまで行 われたかは明かでないが, 近年再び同様の系が組まれ, $\mathrm{OmpF}$ タンパクや PhoA タンパクはタンパク合成終了 後にも分泌すること, 即ち少なくともこれらの細菌の夕 ンパクでは, 合成と分泌は必ずしも共役していなくても よいこと (post-translational translocation) が複数 の研究室から報告されている34,49-52). また後述するよ うに, 無細胞系の研究はタンパク分泌のエネルギー的問 題を解決するために必須の研究法である.

以上のように, 各種変異株と無細胞系の知見から, 大 腸菌においても, 動物細胞と同じものではないが, 分泌 に関与するタンパク性の装置が, 膜や細胞質に存在して 機能していることは間違いないと考えられる.

\section{膜通過のエネルギー}

\section{I 細胞レベルの解析}

タンパクの膜通過のためのエネルギーが，なににより 供給されるかという問題は, 一方ではタンパクの膜通過
が co-translational かpost-translationalかという問 題と密接に関連している. post-translational な場合 には膜の高エネルギー状態即ち proton motive force (PMF) とか膜に存在してATPなどの高分子物質の加 水分解により生じるエネルギーを必要とするタンパク性 の分泌装置の関与が考えられる. co-translational の 場合にはそれにポリペプチド鎖の伸長のエネルギーも考 えにいれておかなければならない.

細胞そのものでこのエネルギーの問題を検討したの は, 各種の呼吸阻害剤やイオノフォアを用いた実験であ る.

たとえば Daniels ら ${ }^{53)}$ はペリプラズムタンパクのロ イシン結合タンパクや $\beta$-ラクタマーゼはプロトン・イ オノフォアである CCCP (caronylcyanide $m$-chlorophenylhydrazone) やカリウム・イオノフォアである バリノマイシンで処理することにより分泌しなくなり, 前駆体が蓄積する．これらの処理は膜電位を消失させる ことから, ペリプラズムタンパクの分必には膜電位が必 要と推定された. Enequist ら 54) もジニトロフェノール や CCCP 処理で, 外膜の $\mathrm{OmpF}$ タンパク, OmpA タン パク, LamB タンパク, ペリプラズムのマルトース結 合タンパク, アラビノース結合タンパクの前駆体のプロ セシングが阻害されることから proton motive force ( $\mathrm{PMF})$ がタンパクの膜通過に必要なことを報告してい る.さらにこれらの薬剤が $\mathrm{PMF}$ 以外に膜に障害を与 えている可能性を除くため, プロトンATPase の欠損 の unc A 変異株を嫝気的に培養することにより, PMF を低下させ，このときもプロセシングが著しく阻害され ることを示した. しかし PMF の低下は細胞外栄養素 の膜透過を低下させ, ATP レベルの低下なども引き起 こしてしまうので, 㛜密な結論を避けている. Bakker

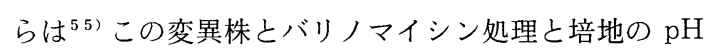
変化の組合せにより， $\beta$-ラクタマーゼのプロセシング の 1/2 阻害は PMF が $150 \mathrm{mV}$ に低下したときにおこ り, ATP レベルには関係がないと報告している.

しかし，この様な特定のステップに関する知見を生菌 全体を用いて得るのは多くの場合厳密性をかく，それは ある変異なり薬剂処理に対して細胞は全体として対応 し，二次的・三次的な効果がおこるからである。それを 防ぐためには, 厳密に条件をコントロールされた無細胞 系による検討がなされなければならないと考えられる.

\section{II オルガネラでの知見}

ミトコンドリアや葉緑体のような真核生物のオルガネ 
ラの構成タンパクは一部はオルガネラ内の DNA に コードされているが, 大部分は核染色体の DNA にコー ドされており, 細胞質のリボソームで翻訳された後に各 オルガネラの特定の部位に局在化する．細胞質内に作ら れた可溶性の前駆体は各オルガネラに向かうための sorting signal 配列を持っており, post-translational に 局在化することができる．このとき，多くのミトコンド リアタンパクの移行のためにはオルガネラの膜が高エネ ルギー状態にあることが必要なことが，無細胞系のイオ ノフォア添加実験により示されている. またポリンなど いくつかのオルガネラの膜タンパクでは高エネルギー状 態にない膜にも入り込めることが示されている ${ }^{56)}$.

\section{IIIIM13 コートタンパクの内膜への移行}

M13 は大腸菌雄株の性繊毛先端に吸着感染する一本 鎖ファージであるが, このコートタンパクは感染した大 腸菌の内膜に先ずアセンブルし，子ファージ DNA が 細胞からしみだして行くときに DNA 結合タンパクと 置き変わるようにしてファージを包んで菌体外に放出さ れる. アミノ酸 50 個からなる比較的小さなタンパク で, $\mathrm{N}$ 末端が酸性, 中央部分が疎水性, $\mathrm{C}$ 末端が塩基性 のアミノ酸に富む構造をしているが，その前駆体は $\mathrm{N} 末$ 端に更に 23 アミノ酸のシグナル配列をもっている．野 生型ファージのパルス・チェイス実験でこのコートタン パクの前駆体は先ず細胞質の可溶性画分に作られた後に 膜にアセンブルするという結果が得られ，アセンブリー の遅い変異株の実験からもこのことが確認された ${ }^{57)}$.

次いでこの M13 コートタンパク前駆体の成熟型への 切断を指標にして，大腸菌のシグナルペプチダーゼが部 分精製され，更にマルチコピープラスミドにクローンさ れた遺伝子を持つ株を用いて，この酵素が大量に精製さ れるようになった ${ }^{58)}$ 。このシグナルペプチダーゼには M13 コートタンパクばかりでなく, 多くの大腸菌の分 泌タンパク・膜タンパクの前駆体からシグナル配列を切 断する活性が認められた．この酵素の切断するシグナル 配列のC末端アミノ酸はアラニンである.

精製した M13 ファージコートタンパクと人工的膜小 胞と精製したシグナルペプチダーゼのみからなる無細胞 系か組まれて，この3者のみによって post-translational に前駆体の膜への組み込みとプロセッシングが起こるこ とが示されている ${ }^{59)}$.このときの膜小胞は高エネル ギー状態でなければならないので，この系では夕ンパク の膜への組み込みのエネルギーは膜の PMF と考えら れた.
この実験はまた Wickner らがシグナル仮説に対抗す る形で提唱した membrane trigger 仮説を支持するも のとされている. 即ち, 前述したように膜タンパクの前 駆体はシグナル配列の存在により成熟体とは異なる高次 構造をとっていて可溶性であるが，シグナル配列と膜之 の出会いによりタンパクの高次構造に変化が起こって, それにより膜への組み込みが起こり，次いでシグナル配 列の切断により新たな安定した高次構造になるというも のである.

\section{IV 無細胞系による解析}

Rhoads らによる無細胞タンパク分泌系でも ${ }^{511}$, 生 菌を用いたときと同じく，プロトン・イオノフォアの FCCP $50 \mu \mathrm{M}$ やカリウム・イオノフォアのバリノマイ シン $1 \mu \mathrm{M}$ により PMF を低下させると, PhoA タン パクと OmpA タンパクの小胞内への移行が著しく阻害 されることが示された. しかし，翌年同じグループか ら, PhoA タンパクや OmpA タンパクが post-translational にも膜小胞内に移行することが示され ${ }^{34)}$ ，それ を利用してタンパク合成を終了後に前駆体を精製して加 える分泌系を組んだところ，異なる結果が得られ ${ }^{52)}$ ， 先の結果は使った実験系の様々な不備によるものとされ た。

野生株の膜小胞からなる系に乳酸をくわえると, $\mathrm{PMF}$ と ATP がともに生成される．両方をともに阻害する シアンやジニトロフェノール, CCCP, FCCP を加えれ ば勿論膜通過は阻害される。一方，「ヘキソキナーゼと グルコース」或は「グリセロールキナーゼとグリセロー ル」というような ATP を消費しきる反応系を加えて も，それにより膜通過が阻害された。一方，乳酸のかわ りにATPもしくは ATP 再生産系を加えた系でみる と, シアンやジニトロフェノールは膜通過を阻害せず, CCCP と FCCP は部分的阻害しか起こさなかった。さ らにプロトンATPase の F1 部分を欠失した変異株の 膜小胞を用いた系を組むと，ここでは乳酸から PMF を作っても ATP を作ることができないが，ATP を加 えた系では膜通過がおこり, 乳酸を加えた系では膜通過 がおこらなかった．以上の結果はすべて膜通過のエネル ギーが ATP であることを示している.このことは $\mathrm{F}_{1} \mathrm{~F}_{0}$ プロトン ATPase の完全欠損变異株を用いても追試さ れた ${ }^{60)}$.

以上より，大腸菌では，ATPにより駆動される分泌 装置が膜にあって，全部ではないかも知れないが多くの 


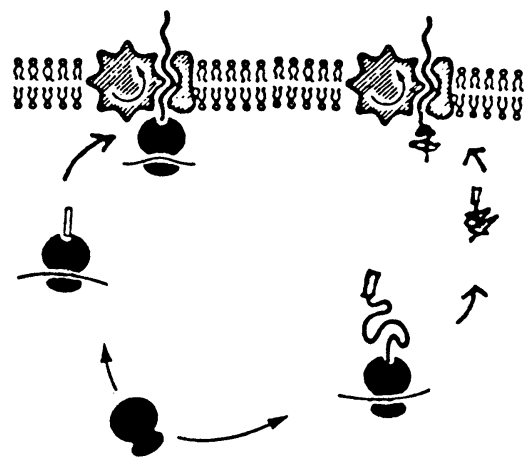

Fig. 3 Tai らの分泌装置のモデル ${ }^{61 \mathrm{c})}$. ATP を エネルギー源とする分泌装置がタンパクを 分泌させる. 同じタンパクでも，シグナル ペプチドが膜に到達するのが速いか遅いか によって co-translatioal (左)にも posttranslational（右）にも分泌し得る.

タンパク質の膜通過に関与していると考えられる (Fig. $3)^{611}$ 。この ATP が膜通過の過程で何に使われるかは 興味深いが, 細菌でも post-translational な膜通過が 起こるということから, すでに出来上がったタンパクの 高次構造を一時的にときほぐすのに必要なのではないか とする考え方が提出されている62).

\section{タンパクの局在性}

\section{I 大腸菌外膜の再構成之局在化機構}

大腸菌の外膜は細胞の最外層にある膜構造で, タンパ クとリン脂質とリポ多糖を含んでいる. リポ多糖は外膜 の外側の層にほぼ局在している.タンパクは量的にみる と $\mathrm{OmpA}$ タンパク, $\mathrm{OmpC}$ タンパク, $\mathrm{OmpF}$ タンパ ク,リポタンパク (Lpp)の 4 種のいわゆる外膜主要夕 ンパクが大部分を占め, あとは比較的小量しか存在しな い.これらのタンパクは分泌タンパクとほぼ同様の機構 で内膜（細胞質膜）を通過した後に外膜にアセンブルす ると考えられる．これらのタンパクの最終的な落ち着き 先をペリプラズムでなく外膜に運命づけているのは何で あろうか.

$\mathrm{OmpC}, \mathrm{OmpF}$ 両タンパクは 3 量体として外膜中に 存在し, 分子量 600 以下の低分子物質を通過させるポ アを形成しているが, このタンパクの高次構造はSDS 中でも安定である. 山田と水島は SDS 溶液中で精製し た $\mathrm{OmpC}, \mathrm{OmpF}$ タンパクとリポ多糖をペプチドグリ カン層上に再構成することに成功している ${ }^{63)}$ 。このと き，ペプチドグリカンにはそれに共有結合したリポタン
パクが付いていることが必須で，またリポ多糖がなくて は規則的な格子配列にはアセンブリーしなかった。 また 彼らは単に形態的に見るだけでなく，T4ファージが吸 着感染する生物学的に活性のある膜の再構成にも成功し ている ${ }^{64)}$. 即ち, これらの外膜成分はその相互作用に より, 元の細胞で形作られるような外膜の基本構造をセ ルフ・アセンブルすることができると考えられる.

OmpA タンパクについては, クローン化した ompA 遺伝子を加工して全 325 アミノ酸の成熟タンパク部分 に様々な大きさの欠失をもつ物を作って発現させると， 少なくとも $\mathrm{N}$ 末端から 193 アミノ酸を持っていないと 外膜に正常に組み込まれないことから, 成熟タンパク部 分の中に外膜に落ち着くための情報が含まれていること が示されている ${ }^{65)}$.

\section{II 移送停止配列}

動物細胞に感染するウイルスのコートタンパクやイム ノグロブリン $\mathrm{M} の \mathrm{C}$ 末端近くには，疎水性アミノ酸の連 続した配列を挟んで, $\mathrm{N}$ 末端側に塩基性アミノ酸, $\mathrm{C}$ 末 端側に酸性アミノ酸をもつような領域があり，これがこ れらのタンパクを膜にとじめるのに重要な働きをしてい ることが示されて, 移送停止配列 (stop transfer sequence) と呼ばれている. 即ち, $\mathrm{N}$ 末端のシグナル配 列から始まったタンパクの co-translational な移送が この配列に至って停止し，この部分で膜につなぎ止めら れると考えられている.

この配列の機能を実証するために, Yost らはプラス ミド上で大腸菌の $\beta$-ラクタマーゼとグロビン遺伝子の 融合したものの間にイムノグロブリンの移送停止配列を 挟んだ物を作り，無細胞系で分泌を検討した ${ }^{66)}$ 。移送 停止配列を挿入する前のものはミクロソーム小胞内に全 体が分泌するが, 移送停止配列を挿入後はまさにその部 分からあとのC末端側は膜内に入り込まないことがプロ テアーゼ感受性により示された.

\section{III タンパクの修飾による局在性決定}

大腸菌の外膜主要タンパクの一つであるリポタンパク は，アミノ酸 58 個からなるが， $\mathrm{N}$ 末端のシステインに 3 本の脂肪酸が 1 つはアミノ基へのアミド結合で $2 つ$ は-SH 基についたグリセロールを介して結合している. このリポタンパクも 20 個のアミノ酸からなるシグナル 配列をもつ前駆体として生合成されるが，リポタンパク に固有なシグナルペプチダーゼの阻害剤であるグロボマ イシンを用いた研究から，先ず前駆体に脂肪酸のついた グリセロールが転移した後シグナル配列が切断されるこ 
とが示された．この脂肪酸による修飾には，シグナル配 列切断点を含む Leu-Ala-Gly-Cys ないし類似の配列 が必要であると考えられている，ついでながら Bacillus licheniformis のペニシリナーゼ前駆体にもこの配列が あるため, 全てが分泌するのではなく, 一部はリポタン パク化して膜結合型となることが示されている ${ }^{67) . ~}$

リポタンパクの外膜への局在化にはこの脂肪酸による 修飾が必須であることが，シグナル配列と成熟 $\mathrm{N}$ 末端 7 アミノ酸を $\mathrm{OmpF}$ タンパクのシグナル配列と $\mathrm{N}$ 末端 11 アミノ酸とすげ替えたタンパクを作ることにより示され た. 即ち,このようにして脂肪酸による修飾を受けなく

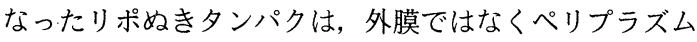
に局在したのである.このことからリポタンパクのタン パク本体はペリプラズムに存在し，その脂肪酸部分が外 膜にアセンブルしているというモデルが提出されてい る.

以上のように，タンパクの局在性の情報は成熟タンパ ク本体のなかにあると考えられる.

\section{終りに}

以上, 細菌のタンパク質の膜透過研究の現状をまとめ た. 日々発展を続けている分野であるので短い期間に新 しい知見が数多く現れてくると思われる，とくに本稿で 問題点として取り上げた点については, 変異株と無細胞 タンパク透過系の組合せにより多くの本質的に重要な新 知見が得られるはずであり，私達もその一端を担うべく アルカリ性ホスファターゼ遺伝子 $p h o A$ を用いた分泌 ベクターを利用し，各種融合タンパクの膜透過を調べる ことによって，検討を進めているつもりである68-70). 読者の皆様にこの分野の面白さが少しでも伝わり，また 多少とも問題点が整理されれば望外の喜びである.

\section{引用文献}

1) H. C. Neu \& L. A. Heppel (1965) J. Biol. Chem. 240, 3685 .

2) T. Miura \& S. Mizushima (1968) Biochim. Biophys. Acta 150, 159.

3) M. J. Osborn et al. (1972) J. Biol. Chem. 247, 3962.

4) S. Mizushima \& H. Yamada (1975) Biochim. Biophys. Acta 375, 44.

5) I. Yamato et al. (1975) J. Biochem. 77, 705.

6) K. Ito et al. (1977) Cell 11, 551.

7) C. A. Schnaitman (1971) J. Bacteriol. 108, 545 .
8) C. Filip et al. (1973) J. Bacteriol. 115, 717.

9) J. P. Rosenbusch (1974) J. Biol. Chem. 249, 8019

10) G. Blobel \& B. Dobberstein (1975) J. Cell Biol. 67, 835 .

11) P. Walter \& G. Blobel (1980) Proc. Natl. Acad. Sci. USA 77, 7112

12) L. L. Randall \& S. J. S. Hardy (1984) Microbiol. Rev. 48, 290.

13) D. Koshland \& D. Botstein (1980) Cell 20, 749.

14) D. Koshland et al. (1982) Cell, 30, 893.

15) B. D. Davis \& P.-C. Tai (1980) Nature 283, 433.

16) J. M. DiRienzo et al. (1978) Ann. Rev. Biochem. 47, 481.

17) W. Wickner (1979) Ann. Rev. Biochem. 48, 23.

18) S. D. Emr et al (1980) J. Cell Biol. 86, 701.

19) W. Wickner (1980) Science 210, 861.

20) G. Kreil (1981) Ann. Rev. Biochem. 50, 317.

21）依田幸司，田村學造 (1981) 蛋白質核酸酵素 26, 386 .

22) 伊藤維昭 (1981) 生化学 53, 427.

22a) 伊藤維昭, 芝清隆, 秋山芳展 (1985) 細胞工学 4, 1172.

23) D. D. Sabatini et al. (1982) J. Cell Biol. 92, 1.

24) S. D. Emr \& T.J. Silhavy (1982) J. Cell Biol. 95, 689 .

25) S. Michaelis \& J. Beckwith (1982) Ann. Rev. Microbiol. 36, 425 .

26) T. J. Silhavy et al. (1983) Microbiol. Rev. 47, 313.

27) D. Oliver (1985) Ann. Rev. Microbiol. 39, 615.

28) S. A. Benson et al. (1985) Ann. Rev. Biochem. $54,101$.

29) P. Walter \& G. Blobel (1981) J. Cell Biol. 91, 551.

30) P. Walter \& G. Blobel (1982) Nature 299, 691.

31) L. Lauffer et al. (1985) Nature 318, 334.

32) E. A. Evans et al. (1986) Proc. Natl. Acad. Sci. USA 83, 581.

33) G. Heijne (1979) Eur. J. Biochem. 97, 175.

34) L. Chen et al. (1985) J. Bacteriol. 161, 973.

35) J. A. Rothblatt \& D.I. Meyer (1986) EMBO Journal 5, 1031.

36) H. Bedouelle et al. (1980) Nature 285, 78.

37) S. D. Emr et al. (1980) Nature 285, 82.

38) S. Inouye et al. (1982) Proc. Natl. Acad. Sci. USA 79, 3438

39) D. B. Oliver \& J. Beckwith (1981) Cell 25, 765.

40) D. B. Oliver \& J. Beckwith (1982) J. Bacteriol. 150,686 .

41) D. B. Oliver \& J. Beckwith (1982) Cell 30, 311.

42) C. A. Kumamoto \& J. Beckwith (1983) J. Bacteriol. 154, 253.

43) K. Ito et al. (1983) Cell 32, 789.

44) K. Shiba et al. (1984) EMBO Journal 3, 631.

45) Y. Akiyama \& K. Ito (1985) EMBO Journal 4, 3351. 
46) J. Jarvik \& D. Botstein (1975) Proc. Natl. Acad. Sci. USA 72, 2738.

47) H. Inouye \& J. Beckwith (1977) Proc. Natl. Acad. Sci. USA 74, 1440.

48) W. P. Smith (1980) J. Bacteriol. 141, 1142.

49) M. Muller \& G. Blobel (1984) Proc. Natl. Acad. Sci. USA 81, 7421.

50) M. Muller \& G. Blobel (1984) Proc. Natl. Acad. Sci. USA 81, 7737.

51) D. B. Rhoads et al. (1984) J. Bacteriol. 159, 63.

52) L. Chen \& P.C. Tai (1985) Proc. Natl. Acad. Sci. USA 82, 4384.

53) C. J. Daniels et al. (1981) Proc. Natl. Acad. Sci. USA 78, 5396.

54) H. G. Enequist et al. (1981) Eur. J. Biochem. 116, 227.

55) E. P. Bakker \& L. L. Randall (1984) EMBO Journal 3, 895.

56) M. G. Douglas et al. (1986) Microbiol. Rev. 50, 166.

57) K. Ito et al. (1979) Proc. Natl. Acad. Sci. USA 76, 1199 .

58) C. Watts et al (1981) Cell 25, 347

59) T. Date \& W. Wickner (1981) Proc. Natl. Acad.
膜 (MEMBRANE), Vol.12 No.3 (1987)

Sci. USA 78, 6106.

60) L. Chen \& P.C. Tai (1986) J. Bacteriol. 167, 389.

61) P. C. Tai, M.P. Caulfield, D. Furlong, L. Chen \& B. D. Davis (1985) "Protein Transport and Secretion", Cold Spring Harbor Laboratory, New York, 48.

62) J. E. Rothman \& R. D. Kornberg (1986) Nature 322, 209.

63) H. Yamada \& S. Mizushima (1978) J. Bacteriol. $135,1024$.

64) H. Furukawa \& S. Mizushima (1982) J. Bacteriol. 150, 916.

65) U. Henning et al. (1983) Eur. J. Biochem. 136, 233.

66) C. S. Yost et al. (1983) Cell 34, 759.

67) J.-S. Lai et al. (1981) Proc.Natl. Acad. Sci. USA 78, 3506.

68) 山崎真狩, 田村学造 (1983) 化学之生物 21, 649.

69）田村学造, 山崎真狩, 依田幸司 (1985)「バイオテク ノロジ一」(丸尾文治編, 学会出版センター), 396.

70) K. Yoda et al. (1987) "Phosphate Metabolism and Cellular Regulation in Microorganisms" (Ed. A. Torriani-Gorini et al.), in press.

\section{繊維学会宮崎基金国際シンポジウム}

第 3 回 膜——その基礎科学と技術——関するシンポジウム

\section{主 催: 繊維学会 共 催: 日本膜学会, ほか}

日 時：6月13日（土） 15日（月） 9 時〜 18 時

会 場：国立教育会館 6 F 601 号室

参加申込締切：5月30日（土）必着.テキスト郵送希望 者は 5 月 9 日（土）までに送料 700 円を参加費に加算 して打申し込み下さい，5月9日以後の申込み者には 年次大会受付にてお渡し致します。

参加費：(括弧内は期限後・テキスト代を含む.) 賛助・ 維持会員, 共催学会会員 6,000 円 ( 8,000 円), 会員外
10,000 円 ( 12,000 円)

参加申込方法：参加するシンポジウム名, 氏名, 住所, 会員資格打よび連絡先を明記し, 参加費を添えて扣申 し込み下さい。送金方法は現金書留または銀行振込(三 菱銀行目黒支店普通口座 4287837 社団法人繊維学会宛） をご利用下さい。

申込先：干 141 東京都品川区上大崎 3-3-9-208 繊維学 会「各シンポジウム係」あて（電話 03-441-5627）

\section{第 5 回物性物理化学研究会}

主 催: 物性物理化学研究会

共 催: 日本学術会議 化学系・物理系薬学研究連絡委 員会

協 賛: 日本膜学会, ほ力

日 時：昭和 62 年 7 月 3 日 (金) 13:00より

会 場 : 京大会館 101 号室 (京都市左京区吉田河原町 15-9 TEL 075-751-8311)

\section{プログラム}

1. 蛍光検出 HPLC による生体物質の高感度測定 （九大・薬）大倉洋甫

2. ESR.ENDOR 法による有機薄膜の研究 （電総研）黒田新一

3. 旋光法による神経の興奮性膜の活動様式の研究 （生理研）渡辺 昭

4. 一重項酸素および活性酸素種の化学

（京大・工）松浦輝男
5. 繊維製品の燃焼性と熱分解ガスの毒性について

6. 多重膜における酵素反応を伴う拡散の研究 （阪市大・生）岩崎 錦

7. 錠剂の表面粗さに及ぼす製造条件の影響 （名市大・薬）米勢政勝

（藤沢薬工）豊島健三 懇親会：18:00より京大会館 102 号室にて 会費 6,000円 参加申込：八ガキに氏名, 所属, 連絡先, 懇親会参加の 有無を記して 6 月 30 日までに下記宛にお申し込み下さ い。な扔，懇親会費は当日受付で扔払い下さい。

連絡先：干 606 京都市左京区吉田下阿達町 京都大学薬学部薬品物理化学教室内 物性物理化学研究会

(世話人) 宮嶋 孝一郎 TEL (075) 751-2111 内線 4565 